\title{
VIEWS OF ZULUS AND SOUTHERN SOTHOS ON IMIMUNISATION
}

ALWYN JOHANNES LUBBE

$$
\text { B.A. (HONS) }
$$

\section{Senior Researcher, Institute for Communication Research, Human Sciences Research Council.}

\section{INTRODUCTION AND AIM}

The promotion of good health and the prevention of disease are two of the aims of community health care that can, to a large extent be realised by means of immunisation. Immunisation does not only make it possible to control the spread of a number of infectious diseases, but also enhances the overall health status of a community.

In a report from the United Nations International Childrens' Emergency Fund, it is pointed out that ... immunisation of all children against the major diseases would also be an indirect immunization against malnutrition itself. Any increase in protection against malnutrition would, in its turn, reduce the risk of infection. A malnourished child who contracts measles, for example, is approximately 400 times more likely to die of the disease than a child who is adequately fed. ${ }^{4}$

In order to enhance the general state of heatlh of a community, it is furthermore necessary to introduce health guidance programmes by means of which encouragement can be given for the development of a sense of responsibility in order to obtain active participation in health

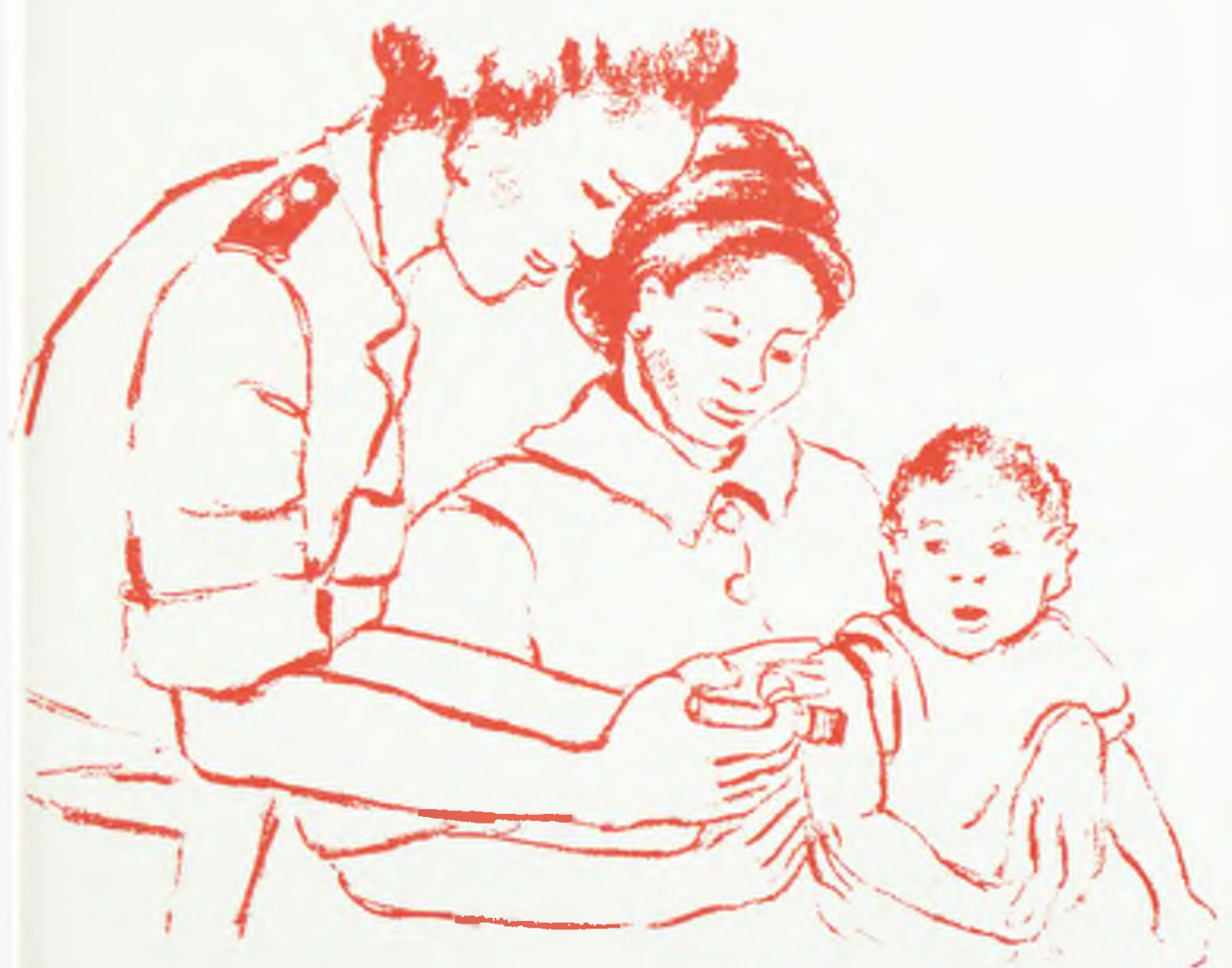

\section{OPSOMMING}

Hierdie navorsing is deur die Raad vir Geesteswetenskaplike Navorsing in samewerking met die Departement van Gesondheid en Welsyn onderneem. Die doel met die navorsing was om stedelike en landelike Zoeloes en Suid-Sotho's se sienswyses oor immunisasie na te gaan. Volgens die bevindings wil dit voorkom of veral persone in die landelike ondersoekgebiede onbewus was van die benutting en waarde van immunisasie.

care. However, guidance can only best be given if the counsellor keeps abreast of the views of a community on specific health matters.

Against this background the Human Sciences Research Council and the Department of Health and Welfare, as a part of an extensive project, conducted an investigation into the views of inter alia urban and rural Zulus and Southern Sothos with regard to health matters. $^{2,3}$

\section{SAMPLES AND DATA COLLECTION}

The project was carried out among urban and rural Zulu and Southern Sotho men and women between the ages of 15 and 64 . The urban research areas were Soweto, Durban and Bloemfontein, whereas Balfour/Standerton, Bergville and Dewetsdorp were included in the rural investigation.

In order to compose representative samples in the research areas involved, the names of a number of street blocks (urban) and farms (rural) were drawn at random. A number of residential units were next drawn from the selected areas, and only one person per residential unit was eventually selected in a random manner. The composition of the samples, subdivided according to research area, age and sex is explained in Table 1. 
Table 1 Composition of the samples according to research area, age and sex

\begin{tabular}{|c|c|c|c|c|}
\hline & Age & $\begin{array}{l}\text { Men } \\
\%\end{array}$ & $\begin{array}{l}\text { Women } \\
\% \\
\end{array}$ & $\begin{array}{l}\text { Total } \\
\%\end{array}$ \\
\hline URBAN RESEARCH AREAS & & $(\mathrm{N}=53)$ & $(\mathrm{N}=79)$ & $(\mathrm{N}=132)$ \\
\hline Zulus: Soweto & $\begin{array}{l}15-39 \\
40-64\end{array}$ & $\begin{array}{l}66 \\
34 \\
(N=63)\end{array}$ & $\begin{array}{l}70 \\
30 \\
(\mathrm{~N}=69)\end{array}$ & $\begin{array}{l}68 \\
32 \\
(\mathrm{~N}=132)\end{array}$ \\
\hline Zulus: Durban & $\begin{array}{l}15-39 \\
40-64\end{array}$ & $\begin{array}{l}71 \\
29 \\
(N=50)\end{array}$ & $\begin{array}{l}76 \\
24 \\
(\mathrm{~N}=82)\end{array}$ & $\begin{array}{l}73 \\
27 \\
(\mathrm{~N}=132)\end{array}$ \\
\hline Southern Sothos: Soweto & $\begin{array}{l}15-39 \\
40-64\end{array}$ & $\begin{array}{l}70 \\
30 \\
(\mathrm{~N}=58)\end{array}$ & $\begin{array}{l}72 \\
28 \\
(\mathrm{~N}=74)\end{array}$ & $\begin{array}{l}72 \\
28 \\
(\mathrm{~N}=132)\end{array}$ \\
\hline Southern Sothos: Bloemfontein & $\begin{array}{l}15-39 \\
40-64\end{array}$ & $\begin{array}{l}66 \\
34\end{array}$ & $\begin{array}{l}63 \\
37\end{array}$ & $\begin{array}{l}65 \\
35\end{array}$ \\
\hline RURAL RESEARCH AREAS & & $(\mathbf{N}=68)$ & $(N=64)$ & $(\mathrm{N}=132)$ \\
\hline Zulus: Balfour/Standerton & $\begin{array}{l}15-39 \\
40-64\end{array}$ & $\begin{array}{l}72 \\
28 \\
(N=60)\end{array}$ & $\begin{array}{l}67 \\
33 \\
(N=72)\end{array}$ & $\begin{array}{l}70 \\
30 \\
(\mathrm{~N}=132)\end{array}$ \\
\hline Zulus: Bergville & $\begin{array}{l}15-39 \\
40-64\end{array}$ & $\begin{array}{l}78 \\
72 \\
(\mathrm{~N}=51)\end{array}$ & $\begin{array}{l}72 \\
28 \\
(\mathrm{~N}=81)\end{array}$ & $\begin{array}{l}75 \\
25 \\
(N=132)\end{array}$ \\
\hline Southern Sothos: Balfour/Standerton & $\begin{array}{l}15-39 \\
40-64\end{array}$ & $\begin{array}{l}67 \\
33 \\
(N=48)\end{array}$ & $\begin{array}{l}68 \\
32 \\
(\mathrm{~N}=84)\end{array}$ & $\begin{array}{l}67 \\
33 \\
(\mathrm{~N}=132)\end{array}$ \\
\hline Southern Sothos: Dewetsdorp & $\begin{array}{l}15-39 \\
40-64\end{array}$ & $\begin{array}{l}62 \\
38\end{array}$ & $\begin{array}{l}71 \\
29\end{array}$ & $\begin{array}{l}68 \\
32\end{array}$ \\
\hline
\end{tabular}

The data was obtained by means of a questionnaire that had been translated into Zulu and Southern Sotho. The questionnaires were completed by Black fieldworkers during interviews with the questionees (respondents). Before the investigation was launched, the questionnaire was tested by means of a preliminary investigation and the fieldworkers concerned were properly trained in the technique of interviewing people.

\section{FINDINGS}

The findings of the investigation into the views of Zulus and Southern Sothos with regard to immunisation can be summarised as follows:

\section{Awareness of immunisation}

In order to determine the awareness of the respondents with regard to immunisation, it had first to be ascertained whether they had ever before heard of immunisation. The following percentage of respondents in the respective urban reseach areas indicated that they had heard of immunisation: Zulus (Soweto): 95; Zulus (Durban): 80;
Southern Sothos (Soweto): 74 and Southern Sothos (Bloemfontein): 96. From these figures it can be deducted that the majority of the urban Zulus and Southern Sothos were in fact aware of immunisation.

As far as the rural research areas were concerned, the percentage was: Zulus (Balfour/Standerton) 67; Zulus (Bergville): 89; Southern Sothos (Balfour/Standerton): 73 and Southern Sothos (Dewetsdorp): 50 .

Those who claimed to know what immunisation was, were asked a number of additional questions on immunisation, such as the age at which a child should receive the first immunisation and the diseases against which people could be immunised.

\section{Immunisation}

When asked why children had to be immunised, the majority of both the urban ( 81 to $94 \%$ ) and rural (56 to $92 \%$ ) respondents who had been aware of immunisation were of the opinion that the aim of immunisation was to prevent disease. Less than a third of the respondents in the different research areas referred specifically to the prevention of infectious diseases.

\section{First immunisation}

Respondents were also questioned on the age at which a child should be immunised for the first time. According to the Department of Health and Welfare a child should be immunised against as many of the common infectious diseases as possible during the first year of his life. It is desirable to have administered the first dose of the majority of these immunisations by the age of three months. For example, B.C.G. can be administered shortly after birth, whereas the first dose of D.P.T. and poliomyelitis vaccine should be administered at the age of three months. ${ }^{1}$

According to the vast majority (between 83 and $95 \%$ ) of the urban respondents, a child should be immunised for the first time within the first three months after birth. As far as the rural research areas were concerned, only between 3 and $27 \%$ of the respondents held a similar view. 
Figure 1 Percentage of respondents who answered correctly

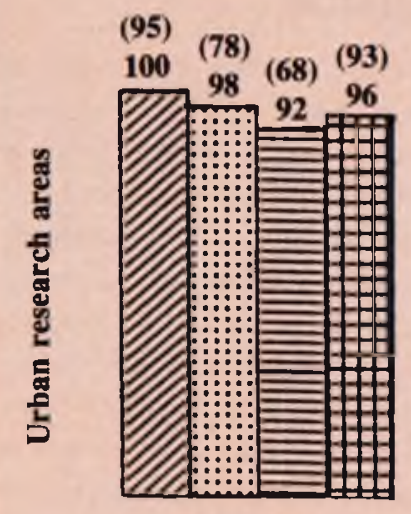

1. Measles**

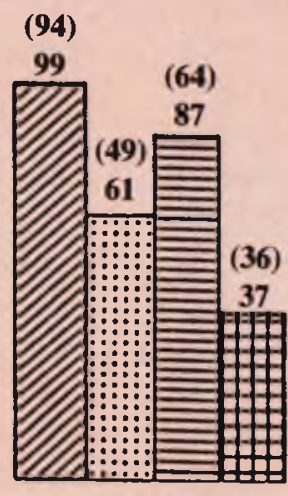

2. Rubella

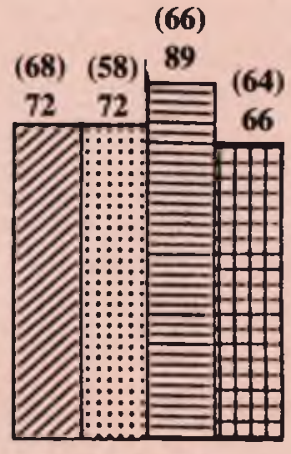

3. Mumps**

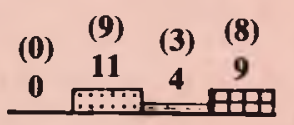

4. Chickenpox

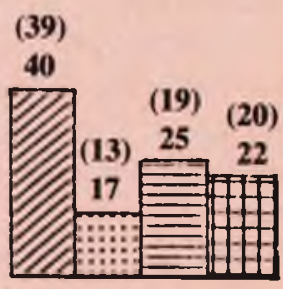

5. Gastro-enteritis

Percentage of respondents who indicated the correct answers: only those respondents who indicated that they knew what immunisation was.

Percentage of respondents from the total samples who indicated the correct answers: percentages between brackets.

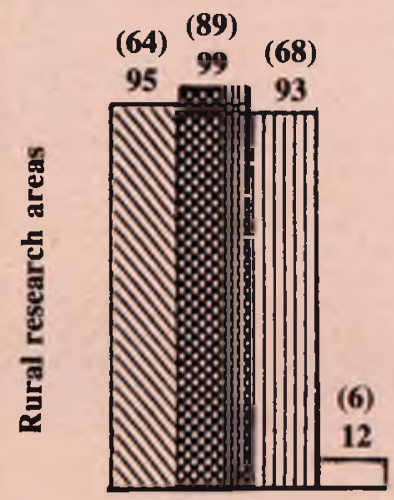

6. Measles

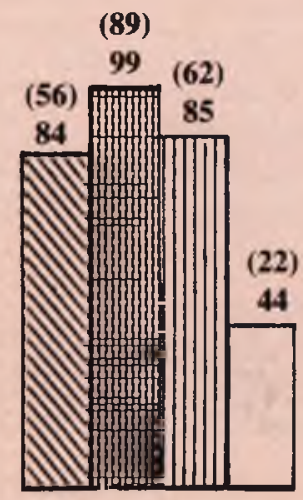

7. Rubella

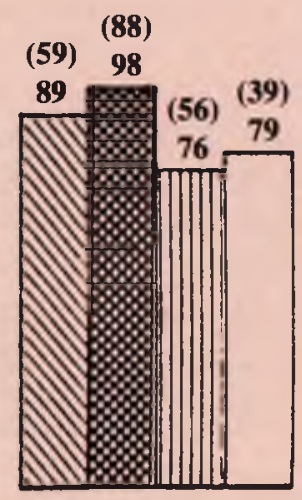

8.Mumps

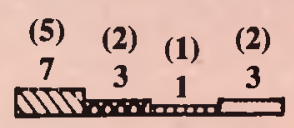

9. Chickenpox*

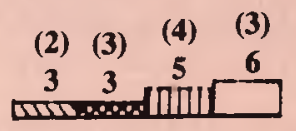

10. Gastro-enteritis*
Zulus:

Soweto

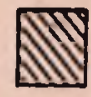

Zulus:

Balfour/

Standerton

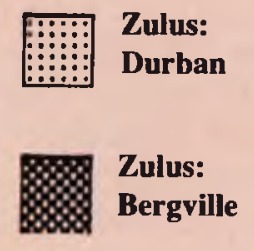

Bergville

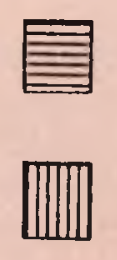

Southern Sothos:

Soweto

Southern Sothos:

Balfour/

Standerton

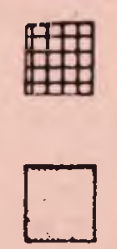

Southern Sothos: Bloemfontein

Southern Sothos: Dewetsdorp

* Because of statistical considerations the data were not analysed.

**Statistical analysis did not reveal significant differences. 


\section{Diseases against which}

\section{people can be immunised}

Those respondents who intimated that they had heard of immunisation were also asked to indicate in respect of a number of questions whether a child could be immunised against these diseases or not. Of the infectious diseases against which immunisation is available, the following were selected for this purpose: measles, rubella (German measles) and mumps. Chickenpox and gastro-enteritis were also included.

There were alarmingly few respondents who provided the correct answers in the case of each of these five diseases. In the urban research areas four repondents indicated five correct answers, whereas only one respondent from the rural areas managed to give the correct answers in the case of all five diseases. It appeared as if correct answers were particularly obtained with regard to three diseases, namely measles, rubella and mumps, whereas answers provided regarding the immunisation against chickenpox and gastro-enteritis were mostly incorrect.

Details of the percentage of respondents who answered correctly are displayed in Figure 1.

\section{Herbalist}

Finally respondents were also asked whether a herbalist was able to protect one against diseases with the help of his medicines. Between $8 \%$ (Zulus: Soweto) and $22 \%$ (Southern Sothos: Soweto) of the urban respondents answered this question in the affirmative. Regarding the rural areas concerned, between $21 \%$ (Southern Sothos: Dewetsdorp) and $55 \%$ (Zulus: Balfour/ Standerton) were of a similar opinion.

\section{FACTORS THAT MIGHT PROBABLY HAVE AFFECTED THE RESPONSES}

In processing the data a statistical method - the logit model of the loglinear technique of analysis was used to determine whether the age, sex and educational level of the respondents had any effect on the answers (responses). The processing of these data was done separately in the urban and rural research areas. Because of statistical considerations the effect of educational level could not be checked in the rural areas of investigation. Furthermore, attention was paid to the role of ethnicity in the responses of both the urban and rural respon- dents. It was however, found that neither of these two factors had any effect on the answers of the respondents.

\section{CONCLUSION}

Despite the fact that the majority (50\% and more) of the respondents in the various research areas were aware of immunisation and were of the opinion that immunisation was used to prevent disease, relatively many of these persons were unable to distinguish between those diseases against which children can be protected by means of immunisation and those diseases for which immunisation cannot be administered. It also became evident that rural respondents in particular were not aware of the necessity of early immunisation.

\section{BIBLIOGRAPHY}

Department of Health. Immunisation: A guide on the administration and storage of vaccines.

Lubbe, A.J., Steyn, Mariana (1981) 'n Gehooranalise met betrekking tot gesondheidsvoorligtingsdienste: Stedelike Zoeloes en Suid-Sotho's se kennis van en houdings teen oor enkele gesondheidsaspekte. Pretoria. Raad vir Geesteswetenskaplike Navorsing.

Lubbe, A.J. (1982) 'n Gehooranalise met betrekking tot gesondheidsvoorligtingsdienste: Nie-stedelike Zoeloes en Suid-Sotho's se kennis van die houdings teenoor enkele gesondheidsaspekte. Pretoria. Raad vir Geestesweten skaplike Navorsing.

United Nations International Childrens' Emergency Fund (1983) State of the World's Children. UNChronicle 2, February 1983 p. 61

\section{BOOKREVIEWS BOEKRESENSIES}

\section{Breastfeeding - how to succeed Questions and answers for mothers}

\section{DEREK LLEWELLYN-JONES (OBE, MD, MAO, FRCOG, FRACOG)}

\section{Faber and Faber, 1983}

The author has made an admirable move by consulting with experienced breastfeeders, namely the highly reputable organisation Nursing Mothers of Australia Association.

The chapter Preparing for breastfeeding is particularly well-done. The illustrations are excellent. It would be advantageous for nursing staff to study this chapter.

Questions that breastfeeding mothers ask makes interesting reading. The author makes a very valid statement in this section regarding test-weighing: is a meddle- some, unscientific procedure, which may cause unnecessary concern to the mother. It tends to make the mother anxious and so reduce the efficiency of the let down reflex.

I feel the author puts unnecessary emphasis on the use of gadgets and formula. I feel very uncomfortable when complimentary feeds are mentioned in a breastfeeding book. Experience indicates that those are greatly abused and can lead to lactation failure.

Otherwise the author gives a well-balanced accurate guide to breastfeeding. He certainly provides the formula for success.

I would recommend the book to midwives, community health nurses, paediatric nurses and medical students.

\section{B L Currie \\ SRN, RM, RICN.}

